\title{
NOMENCLATURAL STUDY OF TETRASTIGMA LEUCOSTAPHYLUM AND TETRASTIGMA RAFFLESIAE (VITACEAE): TWO COMMON HOSTS OF RAFFLESIA IN SUMATRA
}

\author{
Received March 26, 2018; accepted April 30, 2018 \\ YENI RAHAYU, TATIK CHIKMAWATI \\ Department of Biology, Faculty of Mathematics and Natural Sciences, Bogor Agricultural University, Dramaga \\ Campus,Bogor 16680, Indonesia.Email: riinayu23@gmail.com; Email:tchikmawati@yahoo.com
}

\section{ELIZABETH A. WIDJAJA}

Herbarium Bogoriense, Botany Division, Research Center for Biology-LIPI, Cibinong Science Center, Jln. Raya Jakarta-Bogor Km. 46, Cibinong, 16911, Bogor, Indonesia. Current address: RT03 RW01, Kp. Cimoboran, Ds. Sukawening,Dramaga,16680,Bogor, Indonesia.Email: eawidjaja3003@gmail.com

\begin{abstract}
RAHAYU, Y., CHIKMAWATI, T. \& WIDJAJA, E. A. 2018. Nomenclatural study of Tetrastigma leucostaphylum and Tetrastigma rafflesiae (Vitaceae): two common hosts of Rafflesia in Sumatra. Reinwardtia 17(1): 59-66. - A study of Tetrastigma (Miq.) Planch. (Vitaceae) conducted in Sumatra has revealed a number of species records. There are two species were misinterpreted. Two species names are here discussed: T. leucostaphylum (Dennst.) Alston ex Mabb. and T. rafflesiae (Miq.) Planch., which formerly united with T. lanceolarium.
\end{abstract}

Key Words: Nomenclature, Rafflesia, Sumatra, Tetrastigma, Vitaceae.

\begin{abstract}
ABSTRAK
RAHAYU, Y., CHIKMAWATI, T. \& WIDJAJA, E. A. 2018. Studi tatanama Terastigma leucostaphylum dan Tetrastigma rafflesiae (Vitaceae): dua tumbuhan inang Rafflesia di Sumatera. Reinwardtia 17(1): 59-66. Penelitian Tetrastigma (Miq.) Planch. (Vitaceae) di Sumatera telah berhasil mengungkap beberapa catatan jenis. Dua jenis di antaranya salah diinterpretasikan. Kedua nama jenis yang didiskusikan dalam artikel ini adalah: T. leucostaphylum (Dennst.) Alston ex Mabb. dan T. rafflesiae (Miq.) Planch., yang sebelumnya digabungkan ke dalam kelompok jenis T. lanceolarium.
\end{abstract}

Kata kunci: Rafflesia, Sumatera, tatanama, Tetrastigma, Vitaceae.

\section{INTRODUCTION}

Tetrastigma (Miq.) Planch. is an important genus in the grape family (Vitaceae) which are well-known as the exclusive host plants of Rafflesia, a genus of holoparasitic species endemic to South East Asia which contains the largest flower of the world. Some species of Tetrastigma are also used as traditional medicine to cure scabies, treating headaches and fevers in Indonesia, Malaysia, Vietnam and Philippines (Lemmens, 2003). Tetrastigma hemsleyanum Diels \& Gilg ex Gilg is commonly used for treating hepatitis, fever, pneumonia, rheumatism and a sore throat in China (Liu et al., 2002). Tetrastigma is one of the fourteen genera of the grape family Vitaceae which is characterized by unbranched to digitately branched tendrils, a dioecious sexual system and 4-lobed stigmas in pistillate flowers (Suessenguth, 1953; Wen, 2007; Ren, et al. 2011).

There are 95 species of Tetrastigma in the Old World, primarily in the tropics with a few species in temperate Asia (Wen, 2007; Chen et al., 2011a; 2011b). Taxonomists recognized twelve species in the Malay Peninsula (Latiff, 1983), four species in Singapore (Yeo et al., 2012), and five species in
Australia (Jackes, 1989). Sumatra may have served as one of the major routes of dispersal of Tetrastigma from Indochina to west Malesia in the early Oligocene before it became widely distributed in east Malesia in the late middle Miocene (Chen et al., 2011b). The latest study found eleven species of Tetrastigma in Sumatra (Rahayu, 2017).

The taxonomy of Sumatran Tetrastigma, however, has never been systematically revised and is poorly known. Species delimitation and nomenclature of several species has been controversial, such as T. leucostaphylum (Miq.) Planch. Tetrastigma leucostaphylum is one of the species which is found easily in Sumatra. It has been misinterpreted as a synonym of $T$. lanceolarium, since Planchon excluded Tetrastigma from genus Vitis in 1887. Latiff (2001) combined Tetrastigma lanceolarium (Roxb.) Planch. and $T$. leucostapylum to become $T$. tuberculatum. He proposed $T$. tuberculatum (Blume) Latiff as the valid name for the common host of Rafflesia spp. in Malesia. Then, Veldkamp (2008) proposed the common host of Rafflesia spp. is not T. tuberculatum, but T. rafflesiae. However, in 2009 Veldkamp treated $T$. lanceolarium, T. leucostaphylum and $T$. rafflesiae as synonymies of $T$. coriaceum, which is 
the common host of Raflesia spp. in Malesia. Recently, this taxon has been known under various names, such as $T$. lanceolarium (the most popular), T. leucostaphylum, T. rafflesiae, and $T$. coriaceum. This study aimed to clarify the delimitation of Tetrastigma species based on morphological characters, especially concerning the taxonomical confusion of $T$. leucostaphylum and $T$. rafflesiae, the two common hosts of Rafflesia in Sumatra.

\section{MATERIALS AND METHODS}

A morphological study of the genus Tetrastigma in Sumatra was carried out following conventional methods of herbarium taxonomy (de Vogel, 1987; Rifai, 2013). The total number of 59 specimens kept at the Herbarium Bogoriense (BO) were thoroughly examined. They were consisted of 33 old specimens kept at the Herbarium Bogoriense (BO), 23 new specimens collected during the field work in Sumatra and 3 specimens collected from the living collections at the Bogor Botanical Garden (BBG). The field work conducted in the western part of Sumatra, along Bukit Barisan Mountain (West Lampung, Bengkulu, Kaju Aro - Kerinci, Bukit Tiga Puluh National Park - Riau, Sibolangit to Ketambe, Southeast Aceh. The samples which collected from BBG were XVII.F.114.A, XVII.F.72, and XVII.F.96a. Several type specimens kept at BO and the images of some others stored at Kew Herbarium (K), Leiden Herbarium (L) and Paris Herbarium (P) were also studied.

\section{RESULTS AND DISCUSSION}

\section{Morphologycal study}

Tetrastigma (Miq.) Planch. was excluded from genus Vitis by Planchon (1887) based on the key species T. lanceolarium (Roxburgh) Planchon. However, the name of $T$. lanceolarium now has changed to T. leucostaphylllum (Dennst.) Alston ex Mabb. as its older epithet is Cissus leucostaphyla Dennst. The previous Tetrastigma lanceolarium are herein designated as two species, namely $T$. rafflesiae and T. leucostaphylum. Based on the observation of Tetrastigma in Sumatra, it is found that $T$. lanceolarium is a synonym of $T$. leucostaphylum, since the last name is older than the first one. It is also a different species from T. rafflesiae. Details of the characters to distinguish both species are provided in Table 1. Those characters are found on the type specimens and representative specimens examined. There are three new characters which have never been reported, namely petiole length, the length ratio of terminal petiolule and lateral petiolule, and the number of secondary veins.
Tetrastigma leucostaphylum can be identified by leaves having 3-(4)-5 leaflets, rarely with simple leaves, with subcoriaceous, glabrous, lanceolate leaflets, base acute, $8-10$ pairs of secondary veins, petioles shorter $(3-4 \mathrm{~cm})$ than $T$. rafflesiae, the length of terminal petiolule twice as long as the lateral petiolule, and the inflorescence is a corymbose cymes. Tetrastigma rafflesiae characterized by its 3 foliolate, longipetiolate, coriaceous, glabrous, ovate-elliptic leaflets, base cunneate, 7 pairs of secondary veins, terminal petiolule more than twice length of the lateral petiolule, petiole base swollen, sub-umbellated cyme inflorescence with very short to sessile peduncles. During this study, some specimens which were identified as $T$. lanceolarium or T. leucostaphylum in the herbarium are confirmed as $T$. rafflesiae.

\section{The nomenclatural study and species delimitation}

Dennstedt in 1818 published Cissus leucostaphyla based on the Rheede's type specimen, provided as a figure in Hortus Malabaricus 7 t.8 (Rheede 1688: 15), which was called as Vallia tsjori valli in Malabaris. Then C. leucostaphyla was treated as basionym of $T$. leucostaphylum (Dennst.) Alston (Mabberley \& Hamilton, 1977). Roxburgh have seen the Rheede's illustration on Hortus Malabaricus, but he used his own specimen (Roxburgh 2429 as water colour painting at K!) as a type specimen of $C$. lanceolaria. However, Roxburgh is also mentioned Vallia tsjori valli in his description (Roxburgh, 1820). Roxburgh believe that Vallia tsjori valli is a synonym of $C$. lanceolaria. Then Planchon (1887) proposed $C$. lanceolaria to be $T$. lanceolarium, and using Roxburgh 2429 as type specimen, without mentioning Vallia tjsori valli.

In fact, the type specimens of Cissus leucostaphyla (Dennstedt, 1818) and C. lanceolaria (Roxburgh, 1820) are refers to the same Rheede's illustration on Hortus Malabaricus, both name should be synonym. So, it can be concluded that the correct name of $T$. lanceolarium is $T$. leucostaphylum (Dennst.) Alston ex Mabb. as was also mentioned by Shetty \& Singh (1988). Therefore, $T$. lanceolarium is nomen illegitimum based on art. 52, when the type has already have a name. The nomenclature confusion between $T$. lanceolarium and T. leucostaphylum is clearly solved.

Several names have been mentioned by Planchon (1887) as synonym of T. lanceolarium, such as Vitis lanceolaria and $V$. muricata. Vitis lanceolaria Wall. (Wight, 1840) is not supposed to be included in the $T$. lanceolarium group, because it has sessile rough stigma which is never found in the genus Tetrastigma. This statement is confirmed in the illustration no. 28:59 (Wight, 1840), but the illustration no. 177:209 (Wight, 1840) which was 
Table 1. The morphological characters used to distinguish Tetrastigma rafflesiae and T. leucostaphylum.

\begin{tabular}{|c|c|c|}
\hline Characters & Tetrastigma rafflesiae & Tetrastigma leucostaphylum \\
\hline Number of leaflets & 3 leaflets & $3-(4)-5$ leaflets \\
\hline Present of simple leave & Simple leave absent & Simple leave present (rarely) \\
\hline Petioles & Longipetiolate $(7-12 \mathrm{~cm})$ & Shorter than $T$. rafflesiae $(3-4 \mathrm{~cm})$ \\
\hline Petiolules & $\begin{array}{l}\text { Terminal petiolule very long, much longer } \\
\text { than twice the length of lateral ones }(3.5-6 \\
\mathrm{cm}: 0.5-1.5 \mathrm{~cm})\end{array}$ & $\begin{array}{l}\text { Terminal petiolule shorter, only twice longer } \\
\text { than the lateral ones }(2-3 \mathrm{~cm}: 0.5-1.5 \mathrm{~cm})\end{array}$ \\
\hline Petiole base & Swollen & Not swollen \\
\hline Leaf blade & Coriaceous & Subcoriaceous \\
\hline Leaf shape & mostly elliptic & lanceolate \\
\hline Leaf base & Cuneate & Acute \\
\hline $\begin{array}{l}\text { Secondary veins at the } \\
\text { terminal leaflets }\end{array}$ & 7 pairs, prominent & 8-10 pairs, smooth \\
\hline Inflorescences & Subumbellate cymes & Corymbose cymes \\
\hline Peduncle & Very short peduncle to sessile & Short peduncle \\
\hline
\end{tabular}

redrawn from Roxburgh 2429 is the real Cissus lanceolaria Roxb. Therefore, Vitis lanceolaria Wall. is a different species from $C$. lanceolaria and is not synonym with $T$. lanceolarium. The name of $V$. lanceolaria has also been applied to another plant (a homonym).

Vitis muricata published by Wight and Walker-Arnott (in Prodr. Fl. Pen. Ind. Or. 1: 128. 1834) also cited in Hort. Malab. 7: 15, t. 8. Whereas Wall. Num. List No. 6015 and Wight's specimen no. 432 that Wight and Walker-Arnott (1834) also cited in the protologue of $V$. muricata are different and require another name. Thus, $V$. muricata is not synonym of $C$. lanceolaria, and this name is illegitimate based on art. 53 and 54 .

Later, Latiff (2001) proposed the host of IndoMalesia Rafflesia should be $T$. tuberculatum (Blume) Latiff which formerly called as T. lanceolarium. Veldkamp published two papers regarding this problematical name of the host of Rafflesia. Veldkamp (2008) argued that the correct name of Tetrastigma, which is a common host of Rafflesia in Malesia, would be T. rafflesiae Miq., and it is neither $T$. lanceolarium nor T. leucostaphylum. He also mentioned that the combination name which Latiff made ( $T$. tuberculatum) was superfluous. Based on our recent observations, $T$. tuberculatum and $T$. rafflesiae are very distinct. Tetrastigma tuberculatum has tuberculate stem, 3-5 foliolate, ovate leaflets, basal leaflets rounded, while $T$. rafflesiae has lenticellate stem (the lenticels are quite prominent, but not tuberculate), trifoliate, ovate-elliptic leaflets, basal leaflets cunneate, and the base petioles are swollen.
Subsequently, Veldkamp (2009) retracted his statement by submitting a new name, Tetrastigma coriaceum. Since he found the older epithet for $T$. rafflesiae is Cissus coriacea which was proposed by De Candolle in 1824 collected probably by either Riedlé (fide Planchon, 1877: 425) or Leschenault (fide Gagnepain, 1910: 320) in Timor and more fully described by Decaisne in Troisieme (1834). Veldkamp assumed the correct name for the host of Rafflesia spp. must be T. coriaceum (DC.) Gagnep. (Veldkamp, 2009). Unfortunately, T. coriaceum is not found in Sumatra during this study.

Tetrastigma rafflesiae is a name based on the type specimen of Korthals from Mt. Melintang, Sumatra (L!), which was proposed as Vitis rafflesia by Miquel (1863). This species is truely different than $T$. leucostaphylum. We have seen Korthals specimen which were kept in Leiden, sh. 897, 348-162 barcode L0013743, sh. 897, 348-163 barcode L0013744 and barcode L0013742. Although Veldkamp (2008) explained there is no inflorescence on the type specimens kept in Leiden, Miquel (1863) has described the inflorescence characters which we observed as $V$. rafflesiae. Thus, Planchon (1887) proposed this species as $T$. rafflesiae.

Based on this study, $T$. rafflesiae and $T$. leucostaphylllum can be treated as two different species. These species are well-known as host of Rafflesia in Sumatra and had been misapplied. The re-identification of the Sumatran host Rafflesia should be carried out again. Chen et al., (2011a) had listed T. tuberculatum is one of the 
host of Rafflesia in Sumatra (the name of T. tuberculatum was superflous). Recently, people conducted the research of Rafflesia, but did not provide the qualified pictures for identification of its host species. Therefore, the identification of Tetrastigma as specific host of Rafflesia need further study or re-identify.

\section{TAXONOMIC TREATMENT}

Tetrastigma (Miq.) Planch. in de Candolle, Monogr. Phan. 5 (1887) 320, 423; Suessenguth in Engler \& Prantl, Nat. Pfl. Fam. 20d (1953) 318; Backer \& Bakhuizen van den Brink Jr., Fl. Java 2 (1965) 88; Latiff, Gard. Bull. Sing. 36 (1983) 213228. - Type: Tetrastigma leucostaphylum (Dennst.) Alston ex Mabb.

Habit woody climbers. Polygamodioecious. Stems terete, stem surfaces striate and lenticellate, old stems sometimes flattened. Tendrils leafopposed, unbranched or digitately branched, stout or slender. Petiolate, short petioles $(3-9 \mathrm{~cm})$ or longipetiolate (up to $12 \mathrm{~cm}$ ); the length of terminal petiolules and lateral petiolules have ratio 3:1, 2:1 or 1:1. Stipules paired, caducous. Leaves palmately or pedately compound, 3 foliolate, 3-5 foliolate, 5 foliolate or 5-11 foliolate, rarely simple; alternate; leaflets chartaceous to coriaceous, glabrous or sometimes puberulous; margin indented, rarely entire. Inflorescence axillary, cymous, pedunculate. Flowers unisexual, usually pubescent, tetramerous; calyx cupulate; corolla cucculate, tipically cream, white or greenishwhite, caducous; pistillate plant has 4-lobed stigma, ovary cone-shaped, style short, stigma large, ciliolate or nonciliolate, staminodia present; staminate plant has four big anthers, filaments erect, disc obscure, ovary reduced with stigma entire. Berries globose to ellipsoid, fleshy, light green or whitish green when young, orange to red when ripe; seeds 1-4, ovoid, obovoid, ellipsoid or pyriforme; endosperm M-shaped or T-shaped in cross-section.

Habitat and ecology. This genus can be found from 50-2000 $\mathrm{m}$ asl. Their habitat is an open area of lowland to the mountain forest, easily found in the riverside or habitat which has high humidity.

Distribution. Tetrastigma distributed in tropical and subtropical Asia, Malesia (about 95 species), China (24 species), India (16 species) and Australia (5 species). The main distribution area of Tetrastigma in Sumatra is the western part of Bukit Barisan Mountains.

Uses. The obligatory host of Rafflesiaceae, Orang Utan feeding vines, some species used as medicinal plants.

\section{TETRASTIGMA LEUCOSTAPHYLUM \\ (Dennst.) Alston ex Mabb.}

Tetrastigma leucostaphylum (Dennst.) Alston ex Mabb., Alston in Mabberley \& Hamilton, Taxon 26 (1977) 539. Cissus leucostaphyla Dennst., Schlüss. Hort. Malab. (1818) 17, 19, 33. - Type: Vadakkumkoor, 1688, Rheede (a picture in Rheede 1688: 15 t.8 as Vallia-tsjori-valli), see notes.

Tetrastigma lanceolarium (Miq.) Planch. in de Candolle, Monogr. Phan. 5 (1887) 423. nom. illegit. Cissus lanceolaria Roxb. Fl. Ind. 1 (1820) 430. - Type: Kerala, 1820, Roxburgh 2429 ( $C A L$; water-colour painting at $K !)$.

Habit large climber. Stems rough, striate, lenticels prominent, young stems terete, old stems flattened and tuberculate. Tendrils stout, woody, usually simple. Petioles 3-9 cm long; terminal petiolules $(2-3 \mathrm{~cm})$ twice longer than the lateral ones $(0.5-1.5 \mathrm{~cm})$. Leaves pedate, 3-(4)-5 foliolate, rarely simple; leaflets blade subcoriaceous, glabrous; terminal leaflets $13-15 \times 4-6 \mathrm{~cm}$, lanceolate to oblong, base acute, apex acuminate, margin serrate; secondary veins 8-10 pairs, veins inconspicuous/smooth; lateral leaflets lanceolate to oblong, oblique, base acute to rounded, apex and margin as in the terminal leaflets. Inflorescence corymbose cyme; peduncles short, up to $4 \mathrm{~cm}$ long, dark brown, corky. Flowers 1.5-2 mm long, whole parts pubescent; pedicels $2-4 \mathrm{~mm}$ long; 4lobed calyx; corolla green to whitish green, 4 petals $1.5-2 \times 0.75-1 \mathrm{~mm}$; disc restricted to the base of ovary; pistillate has ovary cone-shaped, style short $0.2-0.5 \mathrm{~mm}$ long, 4-lobed stigma, large,

\section{Key to the Sumatran species of Tetrastigma leucostaphylum group}

1.a Short petiole $(3-9 \mathrm{~cm})$, terminal petiolule $(2-3 \mathrm{~cm})$ twice longer than lateral ones $(0.5-1.5 \mathrm{~cm})$, leaflets lanceolate, base acute, secondary veins 8-10 pairs. T. leucostaphylum

1.b Long petiole (up to $12 \mathrm{~cm}$ ), terminal petiolule very long $(3.5-6 \mathrm{~cm})$, more longer than twice length of the lateral ones $(0.5-1.5 \mathrm{~cm})$, leaflets mostly elliptic, base cunneate, secondary veins 7 pairs 
ciliolate; staminate has 4 stamens $c a .1 .5 \mathrm{~mm}$ long, filaments $c a$. $0.75-1.5 \mathrm{~mm}$ long, big anthers $c a .0 .5$ $\mathrm{mm}$ long, oblong. Berries globose $c a .1 \mathrm{~cm}$ across, light green or whitish green when young, orange to red when ripe; seeds 2-4, obovoid; endosperm $\mathrm{M}$-shaped in cross-section.

Habitat and ecology. Tetrastigma leucostaphylum is the most common host of Rafflesia in Sumatra. This species can be found in several habitat types, from the secondary forests, in the edge of the primary forest, rocky cliffs, much depleted dense forest on limestone rock, riverside, plateau forest, until the lowland forest in Sumatra.

Distribution. Indonesia: Java, Sumatra (Fig. 1.). Malay Peninsula. India. Nepal. Bhutan. Bangladesh.

Vernacular name. Daun Jari Lima.

Uses. The leaves used to cure fever in Talang Mamak ethnic, Bukit Tiga Puluh, Riau Province.

Specimens examined. Aceh: Valley of Lau Alas, near tributary of Lau Ketambe, $c a .35 \mathrm{~km} \mathrm{NW}$ of Kutatjane 200-400 m alt., 20 May 1972, W.J.J.O. de Wilde \& B.E.E. de Wilde-Duyfjes 12207 (BO);
Ibid, 21 Mar. 1975, W.J.J.O. de Wilde \& B.E.E. de Wilde-Duyfjes 15650 (BO); Ketambe research station, Alas River valley, $c a .35 \mathrm{~km}$ NW of Kutatjane $3^{\circ} 40^{\prime} \mathrm{N} 97^{\circ} 40^{\prime} \mathrm{E}$ at the primary rain forest 300-500 m alt., 12 Jun. 1979, W.J.J.O. de Wilde \& B.E.E. de Wilde-Duyfjes 18111 (BO); Ketambe research station, in the edge forest near Alas River valley to Lawe Ketambe, 04 Sep. 2014, Y. Rahayu 59 (BO, US); Ibid, Y. Rahayu 61 (BO, US); Ibid, Y. Rahayu 62 (BO, US); Ibid, 05 Sep. 2014, Y. Rahayu 64 (BO, US); Ibid, Y. Rahayu 65 (BO, US); Ibid, $Y$. Rahayu 66 (BO, US); TNGL near Ketambe, Mawas river, 14 May 1981, W. Meijer 15708 (BO); South Atjeh, the lowland forest in or adjacent to the South and South West Parts of TNGL, foot hill forest in the middle of Alas River (Lae Sauraya) area, $2^{\circ} 55^{\prime} \mathrm{N} 97^{\circ} 57^{\prime} \mathrm{E}$, Plateau forest $50-80 \mathrm{~m}$ alt., $25 \mathrm{Jul}$. 1985, W.J.J.O. de Wilde \& B.E.E. de Wilde-Duyfjes 20133 (BO); Ibid, W.J.J.O. de Wilde \& B.E.E. de Wilde-Duyfjes 20307 (BO). North Sumatra: Mt. Singgalang $500 \mathrm{~m}$ alt., 25 May 1918, H.A.B. Bunnemeijer 2746 (BO); Gedong Johore, South of Medan, 04 Feb. 1914, J.A. Lorzing 3534 (BO); Simbahe, North of Sibolangit, 12 Apr. 1918, J.A. Lorzing 5630 (BO); Ibid, 07 Apr. 1926, J.A. Lorzing 11741 (BO). West Sumatra: Sipora, Mentawai Island, 17 Oct. 1924, C. Bolden-Kloss

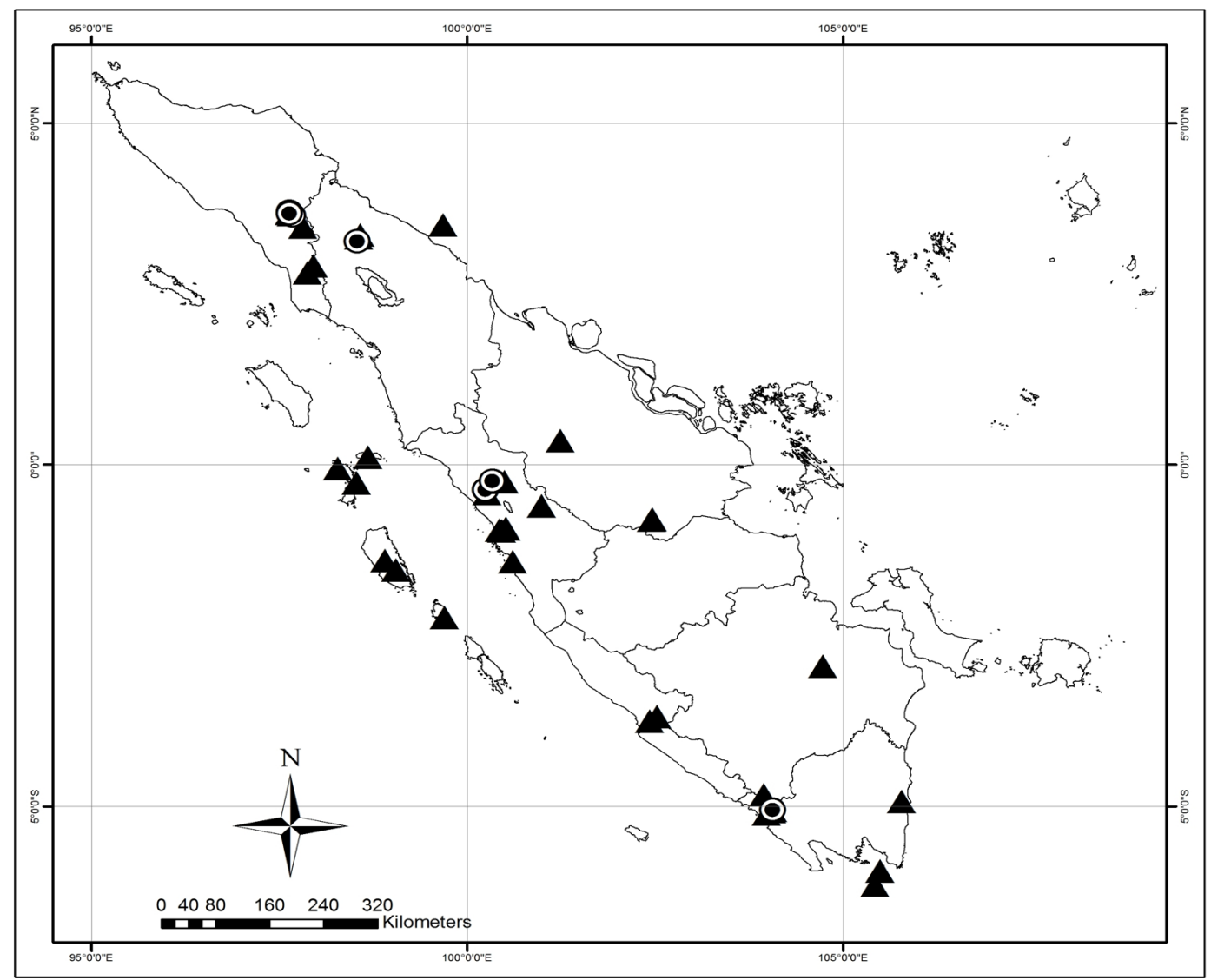

Fig. 1. Distribution map of Tetrastigma leucostaphylum $(\mathbf{\Delta})$ and T. rafflesiae $\left({ }^{\ominus}\right)$ in Sumatra 
14643 (BO); Mentawai, 08 Sep. 1924, Iboet 91 (BO); Ibid, 13 Oct. 1924, Iboet 371 (BO); Batu island, 28 Oct. 1814, Raap 474 (BO); Ibid, 08 Jan. 1844, Raap 612 (BO); Ibid, 10 Jan. 1896, Raap 630 (BO); Ibid, 18 Jan. 1897, Raap 648 (BO); Sibesi island, 22 Apr. 1921, W. Docters van Leeuwen-Reijnvaan 5074 (BO); C.G.G.J. van Steenis 3277 (BO); Rimba Simarasap, Bukittinggi 8001100 m alt., 29 Dec. 1982, Dayar Arbain 108 (BO); Dr. C.D. Duwehand 323 (BO); Barisan range, Muro Kalumpi, Kwantan river near Sijunjung, Japanese railroad $0^{\circ} 36^{\prime} \mathrm{S} 100^{\circ} 59^{\prime} \mathrm{E}$, 03 Mar. 1974, E.F. de Vogel 2789 (BO); Ulugadut, East part of Padang, 06 May 1999, Nakano 99018 (BO); Between Indarung and Air Sirah, East part of Padang, 12 Jun. 1999, Nakano 99040 (BO); TAHURA Bung Hatta, Padang, West Sumatra, 11 Aug. 2014, Y. Rahayu 25 (BO, US); Ibid, Y. Rahayu 27 (BO, US). Riau: Indrapura, 08 Mar. 1954, A.H.G. Alston 14338 (BO); TNBT, Batang Gansal area, along the road to the Papunauan waterfalls, 11 Jul. 2014, Y. Rahayu 01 (BO, US); Ibid, Y. Rahayu 04 (BO, US); Ibid, $Y$. Rahayu 06 (BO); Near Bingkuang lake, Pekanbaru-Bangkinang km.47, Riau, 23 Jul. 2014, Y. Rahayu 07 (BO, US). South Sumatra: Baturadja, South Sumatra, 08 Jul. 1965, H.F. Sun 9968 (BO). Bengkulu: Bengkulu, along the roadway of Kepahiyang, near Bukit Daun, 17 Aug. 2014, Y. Rahayu 29 (BO, US); Ibid, Y. Rahayu 30 (BO, US). Lampung: Estate Wai Liwa, Lampung, 11 Dec. 1921, Iboet 447 (BO); along the roadway of Liwa - Krui, Kubu Perahu, West Lampung, 19 Aug. 2014, Y. Rahayu 44 (BO, US); along the roadway of Liwa - Krui, SW of Kubu Perahu, Balik Bukit district. West Lampung, Ibid, $Y . R a-$ hayu 46 (BO, US); Krakatau island $5 \mathrm{~m}$ alt., 19 Jan. 1922, W. Docters van Leeuwen-Reijnvaan 5970 (BO). Culta: Bogor Botanic Garden, XVII.F.96a, 26 Jan. 2015, Y. Rahayu 69 (BO, US); Bogor Botanic Garden, XVII.F.72, 26 Jan. 2015, Y. Rahayu 72 (BO, US); Bogor Botanic Garden, XVII.F.114a, 26 Jan. 2015, Y. Rahayu 76 (BO, US).

Notes. Veldkamp (2008) mentioned $T$. leucostaphylum is not found in Malesia, but it is found only in Bangladesh, Bhutan, India and Nepal. Based on our observation and by looking at illustration of type specimens of T. leucostaphylum (Rheede, 1688: 15 t.8) and T. lanceolarium (Roxburgh 2429) are similar, and many specimens collected from Sumatra resemble to this species, so specimen from Sumatra which is cited under the specimen examined is T. leucostaphylum.

However, the Rheede's illustration has not been supplied by brief information about its status as type specimen. The place of occurrence mentioned is Berkencour, which is now called Vadakkumkoor, the region south east of Cochin.
The specimen of Roxburgh 2429 also found at Kerala, which is part of Cochin.

2. TETRASTIGMA RAFFLESIAE (Miq.) Planch. Tetrastigma rafflesiae (Miq.) Planch., in de Candolle, Monogr. Phan. 5 (1887) 443. Vitis rafflesiae Miq., Ann. Mus Lugd. Bat. 1 (1863) 75. - Type: West Sumatra, Mt. Melintang, 23 Feb. 1981, Korthals s. n., fide Miquel (isotype L!).

Habit large climber. Stems terete, lenticellate, glabrous. Tendrils stout, woody, simple, tendril arms longer than $20 \mathrm{~cm}$. Petioles $7-12 \mathrm{~cm}$ long, longipetiolate, base of petioles are swollen; petiolules terminal very long $(3.5-6 \mathrm{~cm})$ more longer than twice length of the lateral ones $(0.5$ $1.5 \mathrm{~cm}$ ). Leaves trifoliolate, simple leaves never found, leaflets blade coriaceous, glabrous; terminal leaflets $12-14 \times 4-6 \mathrm{~cm}$, oblong to elliptic, base cunneate, apex acuminate, margin serrate; secondary veins 7 pairs, midrib on the abaxial and adaxial surfaces are prominent; lateral leaflets ovate to elliptic, base, apex and margin as in the terminal leaflets. Inflorescence subumbellate cyme; peduncles short, almost sessile. Flowers $c a .2 \mathrm{~mm}$ long, whole parts pubescent; pedicels $1-2 \mathrm{~mm}$ long; 4-lobed calyx; corolla 4 petals, $1-1.5 \times 0.5-$ $1 \mathrm{~mm}$; disc restricted to the base of ovary; pistillate has ovary ovoid, style short (unclear), 4-lobed stigma, ciliolate, staminodia developed; staminate has 4 stamens, filaments up to $1 \mathrm{~mm}$ long. Berries ellipsoid, $c a$. $0.7-1 \mathrm{~cm}$ across, yellowish green when young, red to dark red when ripe; seeds 1-2, ellipsoid; endosperm M-shaped in cross-section.

Habitat and ecology. Generally in the hills and mountain forest (379-991 m. alt), in the edge of the primary forest and riverside.

Distribution. Indonesia: Sumatra (Fig. 1.).

Specimens examined. Aceh: Ketambe, Valley of Lau Alas, near tributary of Lau Ketambe $c a .35 \mathrm{~km}$ of Kutatjane 200-400 m alt., 31 May 1972, W.J.J.O. de Wilde \& B.E.E. de Wilde-Duyfjes 12478 (BO); Ketambe, along Guhra river 300-350 $\mathrm{m}$ alt., 10 Jun. 1979, W.J.J.O. de Wilde \& B.E.E. de Wilde-Duyfjes 18048 (BO); Ibid, 10 Jul. 1979, W.J.J.O. de Wilde \& B.E.E. de Wilde-Duyfjes 18546 (BO); Ketambe research station, In the edge forest near Alas River valley to Lawe Ketambe, 04 Sep. 2014, Y. Rahayu 58 (BO, US); Ibid, Y. Rahayu 60 (BO, US). North Sumatra: TWA Sibolangit, 04 Aug. 2014, Y. Rahayu 16 (BO, US). West Sumatra: Boekit Batoe Banting 1000-1100 $\mathrm{m}$ alt. Agam, West Sumatra, Aug. 1918, E. Jacobson s.n. (BO); Batang Palupuh, West Sumatra, 21 Aug. 2014, Y. Rahayu 51 (BO, US); Ibid, Y. Rahayu 52 (BO, US); along the road BukittinggiMedan km. 8, near Batang Palupuh, West 
Sumatra, 21 Aug. 2014, Y. Rahayu 53 (BO, US); Lampung: along the roadway of Liwa-Krui, Kubu Perahu, West Lampung, 19 Aug. 2014, Y. Rahayu 43 (BO, US).

\section{ACKNOWLEDGEMENTS}

We would like to thank Dr. Jun Wen for her advisory and very kind help to the first author during this study. We are very much indebted to the director and keeper of the Herbarium Bogoriense (BO) for allowing us to conduct the study at $\mathrm{BO}$. We are very grateful to the directors and keepers of herbaria at P, K, L to use their digitize type specimens. We are also grateful to the forest rangers of Gunung Leuser National Park at Ketambe Research Station, TWA Sibolangit, Batang Papuluh Conservation Forest, Bukit Tiga Puluh National Park, and Bogor Botanic Garden. This work was supported by the Indonesia Ministry of Higher Education through BPPDN scholarships to the first author.

\section{REFERENCES}

BACKER, C. A., BAKHUIZEN VAN DEN BRINK JR. R. 1965. Flora of Java 2. Noordhoff, Groningen.

CHEN, I. 2009. History of Vitaceae inferred from morphology-based phylogeny and the fossil record of seeds. University of Florida, Florida. [PhD. Thesis].

CHEN, P. T., CHEN, L. Q., WEN, J. 2011. The first phylogenetic analysis of Tetrastigma (Miq.) Planch., the host of Rafflesiaceae. Taxon 60: 499-512.

CHEN, P. T., WEN, J., CHEN, L. Q. 2011 b. Spatial and temporal diversification of Tetrastigma (Vitaceae). The Gardens' Bulletin Singapore 63: 307-327.

DECAISNE, J. M. P. 1834. Description d'un herbier de l'ile de Timor, faisant partie des collections botaniques du museum d'histoire naturelle. In: TROISIEME, T. (Ed.). Nouvelles Annales du Museum d'Histoire Naturelle. A La Librairie Encyclopedique de Roret, Paris. Pp. 333-334.

DENNSTEDT, A. W. 1818. Schlüssel Zum Hortus Indicus Malabaricus. Im Verlage des LandesIndustrie-Comptoirs, Weimar.

DE VOGEL, E. F. 1987. Guidelines for the preparation of revisions. In: DE VOGEL, E. F. (Ed.). Manual of Herbarium Taxonomy: Theory and Practice. Unesco Regional Office of Science and Technology for Southeast Asia, Jakarta. Pp. 76-90.

GAGNEPAIN, L. F. 1910. Tetrastigma (Ampelidaceae) nouveaux au peu connus. In: LACOMTE, H. (Ed.) Notulae Systematicae. Herbier du Museum de Paris, Paris. Pp. 262-
273.

JACKES, B. R. 1989. Revision of the Australian Vitaceae 5: Tetrastigma. Austrobaileya 3: 149158.

LATIFF, A. 1983. Studies in Malesian Vitaceae VII: the genus Tetrastigma in Malay Peninsula. The Gardens' Bulletin Singapore 36: 213-228.

LATIFF, A. 2001. Studies in Malesian Vitaceae XII: taxonomic notes on Cissus, Ampelocissus, Nothocissus, Tetrastigma and other genera. Folia Malaysiana 2: 179-189.

LEMMENS, R. H. M. J. 2003. Tetrastigma (Miq.) Planchon. In: LEMMENS, R. H. M. J., BUNYAPRAPHATSARA, N. (Eds.) Plant Resources of South East Asia. Medicinal and Poisonous Plants. PROSEA Foundation, Bogor. Pp. 400-401.

LIU, D., JU, J. H., LIN, G., XU, X. D., YANG, J. S. \& TU, G. Z. 2002. New C-glycosylflavones from Tetrastigma hemsleyanum (Vitaceae). Acta Botanica Sinica 44: 227-229.

MABBERLEY, D. J., HAMILTON, F. 1977. Francis Hamilton's Commentaries with Particular Reference to Meliaceae. Taxon 26 (5/6): 539-540.

MIQUEL, F. A. G. 1863. Ampelidae novae. In: MIQUEL, F. A. G., WILHELM, F. A. (Eds.). Flora Indiae Batavae, supplementum primum prodromus florae Sumatranae. Van der Post, Amsterdam. Pp. 72-95.

PLANCHON, J. E. 1887. Monographie des Ampelidees vraires. In: DE CANDOLLE, A. (Ed.). Monographie Phanerogamarum 5. Sumptibus G. Mason, Paris. Pp. 305-654.

RAHAYU, Y. 2017. Revisi Tetrastigma (Vitaceae) di Sumatera. Institut Pertanian Bogor, Bogor. [M.Sc. Thesis]

REN, H., WEN, J. 2007. Tetrastigma. In: WU, Z. Y., RAVEN, P. H. (Eds.) Flora of China 12. Science Press, Beijing. Pp. 195-208.

REN, H., LU, L., SOEJIMA, A., LUKE, Q., ZHANG, D., CHEN, Z., WEN, J. 2011. Phylogenetic analysis of the grape family (Vitaceae) based on the noncoding plastid trnCPetN, trnH-psbA and trnL-F sequences. Taxon 60(3): 629-637.

RIFAI, M. A. 2013. Asas-asas Sistematika Biologi. Puslit Biologi LIPI, Bogor. Pp. 37-44.

ROXBURGH, W. 1820. Tetrandria monoginia. In: ROXBURGH, W. (Ed.). Flora Indica 1. Thacker Spink Co., Calcutta. Pp. 423-434.

SHETTY, B. V., SINGH, P. 1988. The Vitaceae in Rheede's Hortus Malabaricus. Taxon 37(1): 169-174.

SUESSENGUTH, G. 1953. Vitaceae. In: Engler, A., Prantl, K. (Eds) Dienaturlichen Pflanzen Familien 20. Dunker-Humblot, Berlin. Pp. 318 $-327$.

VAN RHEEDE, H. A. 1688. Horti Malabarici Pars Septima. Sumptibus Johannis van Someren, et 
Joannus van Dyck, Amstelaedami. Pp. 14-15.

VELDKAMP, J. F. 2008. The correct name for the Tetrastigma (Vitaceae) host of Rafflesia (Rafflesiaceae) in Malesia and a (not so) new species. Reinwardtia 12: 261-265.

VELDKAMP, J. F. 2009. Notes on the names of Tetrastigma hosts of Rafflesia. Reinwardtia 13: 75-78.

WEN, J. 2007. Vitaceae. In: KUBITZKI, K. (Ed.). The Families and Genera of Vascular Plants. Springer-Verlag, Berlin. Pp. 468-476.
WIGHT, R. 1840. Icones Plantarum Indiae Orientalis I. J.B. Pharoah, Madras. Pp. 17, 24, 59, 209.

WIGHT, R., WALKER-ARNOTT, G. A. 1834. Prodromus Florae Peninsulae Indiae Orientalis I. Parbury, Allen, \& Co., London. Pp. 128-131.

YEO, C. K., ANG, W. F., ALVIN, F. S. \& LOK, L. 2012. Tetrastigma Planch. (Vitaceae) of Singapore: with a special note of Tetrastigma dichotomum (Bl.) Planch. Nature in Singapore 5: 263-270. 